\title{
Uses of Immunoglobulins as an Antimicrobials Alternative in Veterinary Medicine
}

\author{
Wafaa A. Abd El-Ghany \\ Poultry Diseases Department, Faculty of Veterinary Medicine, Cairo University, 12211 Giza, Egypt \\ *Corresponding author's Email: wafaa.ghany@yahoo.com; (DoRCiD: 0000-0003-1686-3831
}

\begin{abstract}
As a result of increasing the resistance to antimicrobials in the field of veterinary medicine that reflects on human health, there is a great demand to use some drug alternatives. The application of avian immunoglobulins (IgY) is regarded as an important alternative strategy. The IgYs have been produced by several techniques and applied for animals using different methods. In addition, egg yolk IgYs have many advantages over blood type ones. There are many uses of IgYs in veterinary medicine. They have been used for the prophylaxis and treatment of different infections especially the enteric ones in cattle, pigs, rabbits, dogs, rats, mice, and fish species. Moreover, several studies showed the importance of $\mathrm{IgY}$ for competing for the in vivo enteric pathogens in poultry and the in vitro foodborne pathogen. Therefore, it is important to put a spotlight on applications of egg yolk immunoglobulins IgY in veterinary medicine to overcome the problems of antimicrobials' resistance as well as the tissue residues that adversely affect human health.
\end{abstract}

Keywords: Advantages, Animals, Poultry, Production, Yolk antibodies

\section{INTRODUCTION}

The incidence of antibiotic-resistant bacteria (Wierup, 2000), and the demand to control organisms that do not respond to antimicrobials have increased in recent years (Carlander et al., 2000). Therefore, it is of utmost importance to conduct studies related to the use of specific immunoglobulins as an alternative to antimicrobial chemotherapy for infection treatment. Oral passive immunotherapy using specific antibodies is considered a new strategy actively pursued in different clinical studies for the last two decades (Leiva et al., 2020). Immunoglobulins can be defined as glycoproteins secreted by plasma cells after exposure to the specific antigen, and considered as a major component of humoral immunity (Tizard, 2002).

Immunoglobulin $\mathrm{Y}(\mathrm{IgY})$ acts a similar biological character as mammalian $\operatorname{IgG}$, being regarded as the major antibodies against different infectious agents. Accordingly, both IgY and IgG have been used as synonyms, but IgY has become globally accepted relying on its unique features and its origin from the yolk of avian species (Tizard, 2002). The IgY antibodies were found to be transferred from the blood to the egg yolk of chickens for the first time (Klemperer, 1893). A protein of IgY that is known as gamma globulin has been detected in a gamma-livetin fraction of yolk (Williams, 1962). Later on, Leslie and Clem (1969) detected IgY in other parts of the body as duodenum, trachea, and seminal plasma. The concentration of IgY in the blood is $5-6 \mathrm{mg} / \mathrm{ml}$ while in the yolk is $10-25 \mathrm{mg} / \mathrm{ml}$ (Leslie and Martin, 1973; Rose et al., 1974). It is well known that immunoglobulins IgY, IgM, and IgA exist in chicken eggs (Leslie and Clem, 1969). Both IgM and IgA are present in egg white and secreted by the oviduct's mucosa (Rose et al., 1974). However, IgY immunoglobulins are found abundantly in the egg yolk (20 mg of IgY /1 ml, Yegani and Korver, 2010). Although immunoglobulin class IgY is present in a higher concentration in chickens $(5-15 \mathrm{mg} / \mathrm{ml})$, other classes as IgM and $\operatorname{IgA}$ are also present at lower concentrations $(1-3 \mathrm{mg} / \mathrm{ml}$ and $0.3-0.5 \mathrm{mg} / \mathrm{ml}$; respectively) (Leslie and Martin, 1973; Kowalczyk et al., 1985). Immunoglobulins IgY represents about $75 \%$ of the total immunoglobulins in poultry. Egg yolk contains over $100 \mathrm{mg}$ of IgY/egg (Mine and Kovacs-Nolan, 2002; Criste et al., 2020).

Oral immunotherapy using specific IgY antibodies has had an increasing interest in the last decade for the treatment of localized infections (Reilly et al., 1997). The transfer of pathogen-specific immunoglobulins via eggs from hens to their chicks, and their role in the protection of newly hatched chickens from the pathogens have been reported (Hamal et al., 2006; Liou et al., 2010). It has been documented that IgY could be used successfully for scientific, diagnostic, prophylactic, and treatment purposes, as well as preparation of immunochemical reagents, and the formulation of food due to their stability under processing conditions (Raj et al., 2004; Schade and Terzolo, 2006). Immunized chickens with a specific antigen produce antigen-specific IgY which is very important for prophylaxis and control of several diseases especially the enteric ones (Hatta et al., 1993; Hatta et al., 1997; Kovacs-Nolan and Mine, 2012; de Faria et al., 2019). 
Therefore, the present review article focused on the production and advantages of using IgY as a source of specific antibodies. In addition, the article investigated the role of $\operatorname{IgY}$ in the prophylaxis and treatment of different animals, poultry, and foodborne pathogens in humans.

\section{Production of IgY}

First, the production of IgY was a problem. Warr et al. (1995) termed the production and use of IgY antibodies as "IgY Technology". In 1996, the European Centre for the Validation of Alternative Methods (ECVAM) recommended the use of yolk antibodies instead of mammalian antibodies for animal welfare (Schade et al., 1996). The egg yolk contains only class IgY antibodies that can be easily extracted from the yolk by simple precipitation techniques (Gassmann et al., 1990). The antibodies produced in chickens can recognize different epitopes, compared to the antibodies of mammals, and this gives access to a different antibody range than mammalian antibodies (Carlander et al., 1999).

The transfer of IgY from the ovaries to the embryos takes nearly 3-6 days (Patterson et al., 1962). The levels of IgY antibodies in the egg transferred to the offspring were directly related to the circulating levels of IgY in their hens (AlNatour et al., 2004). The selective transfer of IgY from the hen's serum to the membrane of the yolk sac occurs through specific receptors (Tressler and Roth, 1987). The crystalizable constant Fc and hinge regions of the antibody molecule region are required for this transfer (Morrison et al., 2001). In addition, the $\mathrm{CH} 2-\mathrm{CH} 3$ domain is detected by the receptor responsible for IgY transport. During the formation of eggs, IgYs corresponding to IgG in mammals are concentrated in the yolk, whereas IgM and IgA are present in the egg white (Morrison et al., 2001). After hatching, the yolk sac is considered as a good source of a passive humoral immune response as IgY is circulating in the blood, while $\operatorname{IgM}$ and IgA are passing from eggs white to the gastrointestinal tract for localized immunity. Furthermore, protein integrity of the yolk sac is very important for normal absorption of the yolk sac contents, and the transfer of IgY into the chicks' circulation (Ulmer-Franco, 2012).

Different forms of IgY could be used in feed as whole eggs powder, whole yolks powder, water-soluble fraction powder, or purified IgY material. Laying hens should receive either oil emulsion or lipopeptide adjuvanted IgY as primary and booster immunization doses with four to six weeks interval (Schade et al., 1996). However, once the titers of antibodies begin to decline, it is a must to use another booster immunization dose during the laying time. The IgY secreted by B-cells could be detected in chickens' blood in the first week after hatching, and then it gradually declined to start the active immunity (Hamal et al., 2006). Therefore, detection of the protective levels of humoral immunity in chickens depends mainly on the concentration of circulating-IgY in post-hatch. There is a strong positive relationship between the withdrawal of circulating-IgY from the chickens' body and their activity levels during the first week of posthatching, signifying the vital role of IgY in the activation of the chickens' initial immunity (Rehan et al., 2019). The IgY remains in the chickens' blood till the beginning of the second week of age (Smith and Beal, 2008). Accordingly, the adaptive immunity develops during the second week of life, and the early humoral protection in the chickens depends mostly upon the maternal transfer (Hamal et al., 2006). After immunization by a specific antigen, it takes about five to six days for IgY to transfer from the blood, and reach the egg yolk (Smith and Beal, 2008). The concentration of IgY in the yolk is relative to its concentration in the blood (Hamal et al., 2006). Among different avian species as well as the same lines of species, the amount of IgY is greatly variable (Carlander, 2002).

\section{Advantages of using IgY}

Contrary to antimicrobials, IgY antibodies have no side effects, including resistance to diseases or toxic residues, and they are environmentally friendly (Coleman, 1999). As an alternative to antibiotics, passive immunization using IgY antibodies is used to control many infectious diseases (Mine and Kovacs-Nolan, 2002; Schade et al., 2005; Xu et al., 2011). The production of IgY antibodies in hens is much less invasive and stressful, requiring only the collection of eggs rather than the bleeding of the animal (Schade et al., 1991). Besides, rapid induction of a considerable amount of antibodies with a relatively low cost, highly specific and immunogenic, and can be stored at $4^{\circ} \mathrm{C}$ for at least one year in eggs (Rose et al., 1974; Larsson et al., 1991). Production of IgY provides a more hygienic, cost-efficient, convenient, and abundant source of immunoglobulins when compared with the methods used for obtaining antibodies from mammals (Gassmann et al., 1990; Carlander et al., 2000). It has been documented that over $100 \mathrm{mg}$ of IgY can be obtained from one egg indicating high yolk IgY concentrations (Akita and Nakai, 1992). Amro et al. (2018) demonstrated that IgY antibodies could be used as an alternative to mammalian ones, and it is preferable to immunize chickens before laying to avoid the stress of handling that adversely affects egg production.

Immunoglobulins IgY which reacted with rheumatoid factor or human anti-mouse IgG don't interact with the complement or Fc receptors of antibodies (Larsson et al., 1991). So, IgY is an excellent antibody for immunodiagnostic assays that involved mammalian sera. Moreover, they can poorly cross-react with mammalian IgG due to immunological differences. Chickens' IgY antibodies have advantages over mammalian types that they can detect various epitopes and giving access to a wide range of antibody repertoires (Carlander et al., 1999). 
It is well known that ingested IgY antibodies (like other proteins) can be degraded by the action of acidity and proteolytic enzymes in the gastrointestinal tract. Therefore, the inclusion of IgY in the feed in the form of whole egg yolk powder may be a protective and economic method (Jaradat and Marquardt, 2000). In addition, microencapsulation has been found to be another efficient protective method (Chang et al., 2002; Cho et al., 2005; Kovacs-Nolan and Mine, 2005) but it is expesive to perform.

\section{Applications of IgY \\ IgY and different animal species}

There are different uses of IgY, especially in veterinary medicine. Whole eggs or yolk powders have been used as an alternative for the IgY treatment, especially for enteric diseases in various animal species. The mode of action of these IgY has been hypothesized before. This mechanism depends mainly on binding of immunoglobulins to specific bacterial surface epitopes, such as outer membrane protein, lipopolysaccharide, flagella, and fimbriae. After binding, impairment of biological functions of these epitopes may lead to the inhibition of the bacterial growth (Sim et al., 2000) as well as adhesion to the intestinal cells (Yokoyama et al., 1998). Accordingly, IgY could prevent intestinal bacterial adhesion (Girard et al., 2006; Chalghoumi et al., 2009b), and inhibit epithelial cells' invasion (Sugita-Konishi et al., 2002).

IgY antibodies have been used in calves for the prevention of bovine rotavirus (Kuroki et al., 1994; Özpinar et al., 1996; Vega et al., 2011), bovine coronavirus (Ikemori et al., 1997), Salmonella Typhimurium (S. Typhimurium), or S. Dublin (Yokoyama et al., 1998), Yersinia ruckeri, Edwardsiella, Staphylococci, Pseudomonas spp. (Mine and KovacsNolan, 2002), and K99-piliated enterotoxigenic Escherichia coli (ETEC) (Ikemori et al., 1992).

In pigs, different studies have been performed to prevent diarrhea caused by different strains of E. coli, especially in young piglets (Wiedemann et al., 1991; Yokoyama et al., 1992; Yokoyama et al., 1993; Imberechts et al., 1997; Zuniga et al., 1997; Marquardt et al., 1999). Moreover, there was an increase in the growth performance of piglets fed on IgY (Owusu-Asiedu et al., 2003). Similarly, in rabbits, IgY antibodies have been used against diarrhea caused by ETEC infection (O'Farrelly et al., 1992). Pokorova et al. (2000) used IgY for the protection of dogs from canine parvovirus. In rodents, IgY has been used for the prevention of dental caries caused by Streptococcus mutans (Hamada et al., 1991), and for deactivation of urease of Helicobacter pylori (H. pylori ) in rats (Chang et al., 2002), as well as prevention of gastritis in mice (Mony et al., 2019).

Oral administration of egg yolk plasma derived from sialyoligosaccharides, and their derivatives are valuable for the prophylaxis of Salmonella infection in mice (Sugita-Konishi et al., 2002). Lipopolysaccharides elicited a strong immunogenic reaction with the production of a large quantity of specific IgY, so they are potentially applied for inhibition of Salmonella adhesion and prevention of salmonellosis (Sunwoo et al., 1996; Mine, 1997). Mice challenged with S. Enteritidis, and treated with anti- S. Enteritidis flagella $14 \mathrm{IgY}$ showed a survival rate of $77.8 \%$, compared to $32 \%$ in mice fed normal egg yolk IgY (Peralta et al., 1994). In fish, aquarium treatment with anti-Edwardsiella tarda IgY succeeded in the protection of Japanese infected eels (Hatta et al., 1994). Li et al. (2016) showed that egg yolk antibody (IgY) has a protective effect against experimental Vibrio splendidus infection in the sea cucumber.

\section{IgY in poultry}

It has been demonstrated that newly hatched chicks could rely on IgY present in yolk as a source of acquired immunity till complete development of their immune systems occurs (Schade et al., 2005). Maternally derived antibodies are the primary sources of antigen-specific protection in young chickens as they are very susceptible to several pathogens during the first weeks of life due to their undeveloped immune system. Egg yolk IgY immunoglobulins have been used to neutralize specific organisms, especially enteric pathogens. Tamilzarasan et al. (2009) and Diraviyam et al. (2011) concluded that purified chicken immunoglobulins can be used for passive immunization and protection of young chickens against enteric infections. It has been regarded that IgY are effective substitutes to antimicrobials as they can bind with pathogens and inhibit their growth, multiplication and colony-forming abilities (Yegani and Korver, 2007).

Specific IgY antibodies significantly prevented and treated poultry from many bacterial pathogens, such as ETEC (Jin et al., 1998; Karamzadeh- Dehaghani et al., 2020), S. Typhimurium (Kassaify and Mine, 2004b; Chalghoumi et al., 2009a ), S. Enteritidis (Lee et al., 2002; Chalghoumi et al., 2009a), Campylobacter jejuni (C. Jejuni) (Kassaify and Mine, 2004b; Vandeputte et al., 2019), and Gallibacterium anatis (Zhang et al., 2019) as well as infections with infectious bursal disease virus (El Khashab et al., 1995; Eterradossi et al., 1997; Malik et al., 2006; Yousif et al., 2006).

To reduce $S$. Enteritidis shedding in layers chickens, egg yolk powder containing anti-S. Enteritidis antibodies has been given to them (Kassaify and Mine, 2004a). The results revealed that oral treatments with powders in concentrations of $15 \%$ (wt/wt) for 28 days after experimental infection with $S$. Enteritidis induced a rapid reduction as well as a complete elimination of the organisms in the droppings after two weeks of treatments. Moderate to the high percentage of sero-positivity for Salmonella-specific IgY in hens immunized with polyvalent Salmonella bacteria has been detected (Agrawal et al., 2016).

Tsubokura et al. (1997) used egg yolk immunoglobulin IgY from immunized hens for the prevention and treatment of chickens infected with $C$. jejuni. In a preventive study, 14-days old chickens were orally inoculated with $0.5 \mathrm{~g}$ of anti- 
C. jejuni $\operatorname{IgY}$ preparation while in the therapeutic trial, $C$. jejuni-infected chickens were given $0.2 \mathrm{~g}$ of $\operatorname{IgY}$ four days after infection. The reduction in bacterial shedding in the droppings was $99 \%$ and $80-95 \%$ in the preventive and therapeutic studies, respectively. Vandeputte et al. (2019) concluded that yolk IgY revealed a strong reactivity to $C$. jejuni and $C$. coli clonal complexes which reflected the passive immunization of bacterin-derived $\operatorname{IgY}$ to control Campylobacter colonization in poultry.

Broiler chickens treated with hen egg antibody showed a reduction of both C. jejuni and S. Enteritidis intestinal colonization (Wilkie, 2006). Experimentally infected chickens with S. Enteritidis or C. jejuni and treated either orally or in feed with egg yolks powders containing anti-S. Enteritidis or anti-C. jejuni IgY showed measurable IgY activity without significant reduction in the intestinal bacterial colonization. Khalf et al. (2016) demonstrated that oral administration of 40, 20, 10, and $5 \mathrm{IU} / \mathrm{ml}$ of IgY/bird after experimental infection with Clostridium perfringens type A, resulted in protective rates of $96 \%, 88 \%, 80 \%$, and $60 \%$, respectively. In addition, broilers sera of passively immunized chickens revealed antibody titers of 1,2 , and $1.5 \mathrm{IU}$ in the first, second, and third days after immunization, respectively. Brady et al. (2002) detected that fractionated lipoprotein egg yolk from non-immunized hens has an in vitro antibacterial activity against some Streptococcus strains. Lillehoj and Sasai, (1994) and Kim et al. (2001) produced monoclonal IgY against Eimeria spp. causing avian coccidiosis.

\section{Foodborne pathogens}

The protective role of yolk fraction against some foodborne pathogens was identified in vitro (Kassaify et al., 2005). The inhibitory activities of specific IgY on the growth of Salmonella spp. (Lee et al., 2002; Chalghoumi et al., 2009b), E. coli (Sunwoo et al., 2002; Amaral et al., 2008), and Candida albicans (Wang et al., 2008) have been studied previously in vitro. Anti-E. coli O78:K80 IgY immunoglobulins revealed a reduction of in vitro growth of $E$. coli by 1.18 $\log$ colony-forming unit /ml (Mahdavi et al., 2010). It has been documented that IgY immunoglobulins can inhibit bacterial growth and biofilm creation in vitro through binding to the bacterial pathogen (Pereira et al., 2019).

\section{CONCLUSION}

Treatment with IgY is considered as an effective and safe alternative to the traditional treatment with antimicrobial agents. The effects of using IgY for controlling different pathogens in various animal species have been done with very successful results. Therefore, it is crucial to increase the uses of $\operatorname{IgY}$ in the field of veterinary medicine to counteract these significantly important pathogens, to overcome the antimicrobial resistance problem as well as to reduce the level of tissue residues that can affect on the human's health.

\section{DECLARATIONS}

\section{Competing interests}

The author has no conflict of interest.

\section{Authors' contributions}

Wafaa Abd El-Ghany collected all the data, wrote and revised the manuscript.

\section{REFERENCES}

Agrawal R, Hirpurkar SD, Sannat C, and Gupta AK (2016). Comparative study on immunoglobulin Y transfer from breeding hens to egg yolk and progeny chicks in different breeds of poultry. Veterinary World, 9(4): 425-431. Available at: http://www.veterinaryworld.org/Vol.9/April2016/16.pdf

Akita EM, and Nakai S (1992). Immunoglobulins from egg yolk: Isolation and purification. Journal Food Science, 57: 629-634. DOI: https://www.doi.org/10.1111/j.1365-2621.1992.tb08058.x

Al-Natour MQ, Ward LA, Saif YM, Stewart B, and Keck LD (2004). Effect of different levels of maternally derived antibodies on protection against infectious bursal disease virus. Avian Diseases, 48: 177-182. Available at: https://www.jstor.org/stable/1593451

Amaral JA, De Franco MT, Zapata-Quintanilla L, and Carbonare SB (2008). In vitro reactivity and growth inhibition of EPEC serotype O111 and STEC serotypes $\mathrm{O} 111$ and $\mathrm{O} 157$ by homologous and heterologous chicken egg yolk antibody. Veterinary Research Communications, 32 : 281290. DOI: https://www.doi.org/10.1007/s11259-007-9029-3

Amro WA, Al-Qaisi W, and Al-Razem F (2018). Production and purification of IgY antibodies from chicken egg yolk. Journal of Genetic Engineering and Biotechnology, 16: 99-103. DOI: https://www.doi.org/10.1016/j.jgeb.2017.10.003

Brady D, Gaines S, Fenelon L, Mcpartlin J, and O'Farrelly C (2002). A lipoprotein-derived anti-microbial factor from hen-egg yolk is active against Streptococcus species. Journal of Food Science, 67: 3096-3103. DOI: https://www.doi.org/10.1111/j.1365-2621.2002.tb08865.x

Carlander D (2002). Avian IgY antibody: in vitro and in vivo. PhD Thesis - University of Uppsala, Faculty of Medicine (Sweden).

Carlander D, Kollberg H, Wejaker PE, and Larsson A (2000). Peroral immunotherapy with yolk antibodies for the prevention and treatment of enteric infections. Immunologic Research, 21: 1. DOI: https://www.doi.org/10.1385/ir:21:1:1

Carlander D, Stalberg J, and Larsson A (1999). Chicken antibodies: a clinical chemistry perspective. Upsala Journal of Medical Sciences, 104: 179190. DOI: https://www.doi.org/10.3109/03009739909178961 
Chalghoumi R, Marcq C, Théwis A, Portetelle D, and Beckers Y (2009a). Effects of feed supplementation with specific hen egg yolk antibody (immunoglobin Y) on Salmonella species cecal colonization and growth performances of challenged broiler chickens. Poultry Science, 88: 2081-2092. DOI: https://www.doi.org/10.3382/ps.2009-00173

Chalghoumi R, Théwis A, Beckers Y, Marcq C, Portetelle D, and Schneider YJ (2009b). Adhesion and growth inhibitory effect of chicken egg yolk antibody (IgY) on Salmonella enterica serovars Enteritidis and Typhimurium in vitro. Foodborne Pathogens and Disease, 6(5): 593-604. DOI: https://www.doi.org/10.1089/fpd.2008.0258

Chang HM, Lee YC, Chen CC, and Tu YY (2002). Microcapsulation protects immunoglobulin in yolk (IgY) specific against Helicobacter pylori urease. Food and Chemical Toxicology, 67: 15-20. DOI: https://www.doi.org/10.1111/j.1365-2621.2002.tb11351.X

Cho YH, Lee JJ, Park IlB, Huh CS, Baek YJ, and Park J (2005). Protective effect of microencapsulation consisting of multiple emulsification and heat gelation processes on immunoglobulin in yolk. Journal of Food Science, 70(2): 149-151. DOI: https://www.doi.org/10.1111/j.1365$\underline{2621.2005 . t b 07088 . x}$

Coleman M (1999). Using egg antibodies to treat diseases. In Sim JS, Nakai S, Guenter W (ed), Egg nutrition and biotechnology. CAB International, Wallingford, United Kingdom, pp. 351-370. Available at: https://www.cabdirect.org/cabdirect/abstract/20002206464

Criste A, Urcan AC, and Corcionivoschi N (2020). Avian IgY antibodies, ancestors of mammalian antibodies - production and application. Romanian biotechnological letters, 25(2): 1311-1319. DOI: https://www.doi.org/10.25083/rbl/25.2/1311.1319

de Faria LS, de Souza DLN, Ribeiro RP, de Sousa JEN, Borges IP, Ávila VMR, Ferreira-Júnior Á, Goulart LR, and Costa-Cruz JM (2019). Highly specific and sensitive anti-Strongyloides venezuelensis IgY antibodies applied to the human strongyloidiasis immunodiagnosis. Parasitology International, 72: Article number: 101933. DOI: https://www.doi.org/10.1016/j.parint.2019.101933

Diraviyam T, Jeevitha T, Saravanan P, Michael A, and Meenatchisundaram S (2011). Preparation of chicken (IgY) antibodies consortium for the prevention of enteric infections in poultry. Journal of Microbiology and Biotechnology Research, 1: 95-103. Available at: https://bvmj.journals.ekb.eg/article_31276_13d256191505e26b3d213288b4e836a2.pdf

El Khashab EF, Nabarawi AM, Shakal MA, and El Sonosi A (1995). Yolk inoculation in gumboro infected chicken. Veterinary Medical Journal (Giza), 43(1): 103-108. Available at: https://agris.fao.org/agris-search/search.do?recordID=EG9600995

Eterradossi N, Toquin D, Abbassi H, Rivallan G, Cotte JP, and Guittet M (1997). Passive protection of specific pathogen free chicks against infectious bursal disease by in-ovo injection of semi-purified egg-yolk antiviral immunoglobulins. Zentralblatt fur Veterinarmedizin. Reihe B, 44: 371 383. DOI: https://www.doi.org/10.1111/j.1439-0450.1997.tb00988.x

Gassmann M, Thommes P, Weiser T, and Hubscher U (1990). Efficient production of chicken egg yolk antibodies against a conserved mammalian protein. Federation of American Societies for Experimental Biology Journal, 4: 2528. DOI: https://www.doi.org/10.1096/fasebj.4.8.1970792

Girard F, Batisson I, Martinez G, Breton C, Harel J, and Fairbrother JM (2006). Use of virulence factor-specific egg yolk-derived immunoglobulins as a promising alternative to antibiotics for prevention of attaching and effacing Escherichia coli infections. FEMS Immunology and Medical Microbiology, 46: 340-350. DOI: https://www.doi.org/10.1111/j.1574-695X.2005.00030.x

Hamada S, Horikoshi T, Minami T, Kawabata S, Hiraoka J, Fujiwara T, and Ooshima T (1991). Oral passive immunization against dental caries in rats by use of hen egg yolk antibodies specific for cell-associated glucosyltransferase of Streptococcus mutants. Infection and Immunity, 59: 41614167. DOI: https://www.doi.org/10.1128/iai.59.11.4161-4167.1991

Hamal KR, Burgess SC, Pevzner IY, and Erf GF (2006). Maternal antibody transfer from dams to their egg yolks, egg whites, and chicks in meat lines of chickens. Poultry Science, 85: 1364-1372. DOI: https://www.doi.org/10.1093/ps/85.8.1364

Hatta H, Mabe K, Kim M, Yamamoto T, Guiterrez MA, and Miyazaki T (1994). Prevention of fish disease using egg yolk antibody. In Egg Uses and Processing Technologies, pp. 241-249. Availabe at: https://ci.nii.ac.jp/naid/10011969147/

Hatta H, Tsuda K, Akachi S, Kim M, and Yamamoto T (1993). Productivity and some properties of egg yolk antibody (IgY) against human rotavirus compared with rabbit IgG. Bioscience, Biotechnology and Biochemistry, 57(3): 450-454. DOI: https://www.doi.org/10.1271/bbb.57.450

Ikemori Y, Kuroki M, Peralta RC, Yokoyama H, and Kodama Y (1992). Protection of neonatal calves against fatal enteric colibacillosis by administration of egg yolk powder from hens immunized with K99-piliated enterotoxigenic Escherichia coli. American Journal of Veterinary Research, 53(11): 2005-2008. PMID: 1466492

Ikemori Y, Ohta M, Umeda K, Icatlo FCJr, Kuroki M, Yokoyama H, and Kodama Y (1997). Passive protection of neonatal calves against bovine coronavirus-induced diarrhea by administration of egg yolk or colostrum antibody powder. Veterinary Microbiology, 58: 105-111. DOI: https://www.doi.org/10.1016/S0378-1135(97)00144-2

Imberechts H, Deprez P, Van Driessche E, and Pohl P (1997). Chicken egg yolk antibodies against F18ab fimbriae of Escherichia coli inhibit shedding of F18 positive E. coli by experimentally infected pigs. Veterinary Microbiology, 54: 329-341. DOI: https://www.doi.org/10.1016/s0378$\underline{1135(96) 01293-x}$

Jaradat ZW, and Marquardt RR (2000). Studies on the stability of chicken IgY in different sugars, complex carbohydrates and food materials. Food and Agricultural Immunology, 12: 263-272. DOI: https://doi.org/10.1080/09540100020008137

Jin LZ, Baidoo SK, Marquardt RR, and Frohlich AA (1998). In vitro inhibition of adhesion of enterotoxigenic Escherichia coli K88 to piglet intestinal mucus by egg yolk antibodies. FEMS Immunology and Medical Microbiology, 21: 313-321. DOI: https://www.doi.org/10.1111/j.1574695x.1998.tb01179.x

Karamzadeh-Dehaghani A, Towhidi A, Zhandi M, and Mojgan N (2020). Specific chicken egg yolk antibodies against enterotoxigenic Escherichia coli K99 in serum and egg yolk of immunized laying hens. Iranian Journal of Applied Animal Science, 10(1): 155-161. Available at: http://ijas.iaurasht.ac.ir/article_671635.html

Kassaify ZG, and Mine Y (2004a). Effect of food protein supplements on Salmonella Enteritidis infection and prevention in laying hens. Poultry Science, 83: 753-760. DOI: https://wwwdoi.org/10.1093/ps/83.5.753

Kassaify ZG, and Mine Y (2004b). Non-immunized egg yolk powder can suppress the colonization of Salmonella typhimurium, Escherichia coli O157:H7, and Campylobacter jejuni in laying hens. Poultry Science, 83: 1497-1506. DOI: https://www.doi.org/10.1093/ps/83.9.1497

Kassaify ZG, Li EWY, and Mine Y (2005). Identification of antiadhesive fraction(s) in non-immunized egg yolk powder: in vitro study. The Journal of Agricultural and Food Chemistry, 53: 4607-4614. DOI: https://www.doi.org/10.1021/jf0500031

Khalf NM, El-Sawy H, Hanna TN, El- Meneisy AA, and Khodeir MH (2016). Efficacy of IgY immunoglobulin prepared in chicken egg yolk for the protection of chicken against necrotic enteritis. Benha Veterinary Medical Journal, 31(2): 101-105. Available at: https://bvmj.journals.ekb.eg/article 31276_13d256191505e26b3d213288b4e836a2.pdf

Kim JK, Min W, Lillehoj HS, Kim S, Sohn EJ, Song KD, and Han JY (2001). Generation and characterization of recombinant scFv antibodies detecting Eimeria acervulina surface antigens. Hybridoma, 20: 175-181. DOI: https://doi.org/10.1089/027245701750293501

Klemperer F (1893). Ueber natürliche Immunität und ihre Verwerthung für die Immunisirungstherapie. Naunyn-Schmiedebergs Archiv für experimentelle Pathologie und Pharmakologie, 31: 356-382. DOI: https://www.doi.org/10.1007/BF01832882

Kovacs-Nolan J, and Mine Y (2005). Microencapsulation for the gastric passage and controlled intestinal release of immunoglobulin Y. The Journal of Immunological Methods, 296: 199-209. DOI: https://www.doi.org/10.1016/j.jim.2004.11.017 
Kovacs-Nolan J, and Mine Y (2012). Egg yolk antibodies for passive immunity. The Annual Review of Food Science and Technology, 3: 163-182. DOI: https://www.doi.org/10.1146/annurev-food-022811-101137

Kowalczyk K, Daiss J, Halpern J, and Roth TF (1985). Quantitation of maternal-fetal IgG transport in the chicken. Immunology, 54(4): 755-762. DOI: https://www.ncbi.nlm.nih.gov/pubmed/3980047

Kuroki M, Ohta M, Ikemori Y, Peralta RC, Yokoyama H, and Kodama Y (1994). Passive protection against bovine rotavirus in calves by specific immunoglobulins from chicken egg yolk. Archives of Virology, 138: 143-148. DOI: https://www.doi.org/10.1007/BF01310045

Larsson A, Karlsson-Parra A, and Sjöquist J (1991). Use of chicken antibodies in enzyme immunoassays to avoid interference by rheumatoid factors. Clinical Chemistry, 37(3): 411-414. PMID: 2004449.

Lee EN, Sunwoo HH, Menninen K, and Sim JS (2002). In vitro studies of chicken egg yolk antibody (IgY) against Salmonella Enteritidis and Salmonella Typhimurium. Poultry Science, 81: 632-641. DOI: https://www.doi.org/10.1093/ps/81.5.632

Leiva CL, Gallardo MJ, Casanova N, Terzolo H, and Chacana P (2020). IgY-technology (egg yolk antibodies) in human medicine: a review of patents and clinical trials. International Immunopharmacology, 81: 106269. DOI: https://www.doi.org/10.1016/j.intimp.2020.106269

Leslie GA, and Clem LW (1969). Phylogeny of immunoglobulin structure and function. III. Immunoglobulins of the chicken. Journal of Experimental Medicine, 130 (6): 1337-1352. DOI: https://www.dx.doi.org/10.1084\%2Fjem.130.6.1337

Leslie GA, and Martin LN (1973). Studies on the secretory immunologic system of fowl. 3. Serum and secretory IgA of the chicken. Journal of Immunology, 110(1): 1-9. PMID: 4631071

Li X, Jing K, Wang X, Li Y, and Zhang M (2016). Protective effects of chicken egg yolk antibody (IgY) against experimental Vibrio splendidus infection in the sea cucumber (Apostichopus japonicus). Fish and Shellfish Immunology, 48: 105-111. DOI: http://www.doi.org/10.1016/j.fsi.2015.11.024

Lillehoj HS, and Sasai K (1994). Development and characterization of chicken-chicken B cell hybridomas secreting monoclonal antibodies that detect sporozoite and merozoite antigens of Eimeria. Poultry Science, 73: 1685-1693. DOI: https://www.doi.org/10.3382/ps.0731685

Liou JF, Chang CW, Tailiu JJ, Yu CK, Lei HY, Chen LR, and Tai C (2010). Passive protection effect of chicken egg yolk immunoglobulins on enterovirus 71 infected mice. Vaccine, 28: 8189-8196. DOI: https://www.doi.org/10.1016/j.vaccine.2010.09.089

Mahdavi A, Rahmani H, Nili N, Samie A, and Soleimanian-Zad S (2010). Chicken egg yolk antibody (IgY) powder against Escherichia coli O78: K80. Journal of Animal Veterinary advances, 9: 366-373. DOI: http:/www./dx.doi.org/10.3923/javaa.2010.366.373

Malik MW, Ayub N, and Qureshi IZ (2006). Passive immunization using purified IgYs against infectious bursal disease of chickens in Pakistan. Journal of Veterinary Science, 7(1): 43-46. DOI: https://www.doi.org/10.4142/jvs.2006.7.1.43

Marquardt RR, Jin LZ, Kim JW, Fang L, Frohlich AA, and Baidoo SK (1999). Passive protective effect of egg-yolk antibodies against enterotoxigenic Escherichia coli K88+ infection in neonatal and early-weaned piglets. FEMS Immunology and Medical Microbiology, 23(4): 283-288. DOI: https://www.doi.org/10.1111/j.1574-695x.1999.tb01249.x

Mine Y (1997). Separation of Salmonella enteritidis from experimentally contaminated liquid eggs using a hen IgY immobilized immunomagnetic separation system. Journal of Agriculture and Food Chemistry, 45: 3723-3727. DOI: https://www.doi.org/10.1021/jf9701998

Mine Y, and Kovacs-Nolan J (2002). Chicken egg yolk antibodies as therapeutics in enteric infectious disease: a review. Journal of Medicinal Food, 5: 159-169. DOI: https://www.doi.org/10.1089/10966200260398198

Mony TJ, Kwon HS, Won MK, Kang YM, Lee SH, Kim SY, Baek DY, and Elahi F (2019). Anti-urease immunoglobulin (IgY) from egg yolk prevents Helicobacter pylori infection in a mouse model. Food and Agricultural Immunology, 30: 662676. DOI: https://www.doi.org/10.1080/09540105.2019.1617251.

Morrison SL, Mohammed MS, Wims LA, Trinh R, and Etches R (2001). Sequences in antibody molecules important for receptor-mediated transport into the chicken egg yolk. Molecular Immunology, 38: 619-625. DOI: https://www.doi.org/10.1016/S0161-5890(01)00095-5

O'Farrelly C, Branton D, and Wanke CA (1992). Oral ingestion of egg yolk immunoglobulin from hens immunized with an enterotoxigenic Escherichia coli strain prevents diarrhea in rabbits challenged with the same strain. Infection and Immunity, 60: 2593-2597. DOI: https://www.ncbi.nlm.nih.gov/pubmed/1612729

Owusu-Asiedu A, Nyachoti C, and Marquardt R (2003). Response of early-weaned pigs to an enterotoxigenic Escherichia coli (K88) challenge when fed diets containing spray-dried porcine plasma or pea protein isolate plus egg yolk antibody, zinc oxide, fumaric acid, or antibiotic. Journal of Animal Science, 81(7): 1790-1798. DOI: https://www.doi.org/10.2527/2003.8171790x

Özpinar H, Erhard MH, Aytug N, Özpinar A, Baklaci C, Karamüptüoglu S, Hofmann A, and Lösch U (1996). Dose-dependent effects of specific eggyolk antibodies on diarrhea of newborn calves. Preventive Veterinary Medicine, 27: 67-73. DOI: https://www.dx.doi.org/10.1016\%2F0167$\underline{5877(95) 00561-7}$

Patterson R, Youngner JS, Weigle WO, and Dixon FJ (1962). Antibody production and transfer to egg yolk in chickens. Journal of Immunology, 89: 272-278. Available at: https://www.jimmunol.org/content/89/2/272

Peralta RC, Yokoyama H, Ikemori Y, Kuroki M, and Kodama Y (1994). Passive immunization against experimental salmonellosis in mice by orally administered hen egg yolk antibodies specific for 14-kDa fimbriae of Salmonella enteritidis. Journal of Medical Microbiology, 41: 29-35. DOI: https://www.doi.org/10.1099/00222615-41-1-29

Pereira EPV, Van-Tilburg MF, Florean EOPT, and Guedes MIF (2019). Egg yolk antibodies (IgY) and their applications in human and veterinary health: A review. International Immunopharmacology, 73: 293-303. DOI: https://www.doi.org/10.1016/j.intimp.2019.05.015

Pokorova D, Franz J, and Stepanek J (2000). The use of egg yolk immunoglobulin in the diagnostics of canine parvovirus infections. Veterinarni Medicina, 45: 49-54. Available at: https://www.cabdirect.org/cabdirect/abstract/20002210780

Raj GD, Latha B, Chandrasekhar MS, and Thiagarajan V (2004). Production, characterization and application of monoclonal antibodies against chicken IgY. Veterinarski Arhiv, 74(3): 189-199. Available at: https://wwwi.vef.hr/vetarhiv/papers/2004-74-3-2.pdf

Rehan IF, Mohammed HH, Fahmy SG, Elnagar A, Youssef M, and Shanab O (2019). Influence of photoperiod and circulating-IgY on some behavioural patterns of chicks during the first week of life. International Journal of Veterinary Sciences and Animal Husbandry, 4(2): 18-25. Available at: https://www.veterinarypaper.com/archives/2019/4/2/A/4-2-2

Reilly RM, Domingo R, and Sandhu J (1997). Oral delivery of antibodies; Future pharmacokinetic trends. Clinical Pharmacokinetics, 4: 313-323. DOI: https://www.doi.org/10.2165/00003088-199732040-00004

Rose ME, Orlans E, and Buttress N (1974). Immunoglobulin classes in the hen's egg: their segregation in yolk and white. European Journal of Immunology, 4: 521-523. DOI: https://www.doi.org/10.1002/eji.1830040715

Schade R, and Terzolo HR (2006). IgY-technology: application and trends. In: EPC 2006- 12th European poultry conference, Verona, Italy, 10-14 September, 2006. World's Poultry Science Association (WPSA).

Schade R, Calzado EG, Sarmiento R, Chacana PA, Porankiewicz-Asplund J, and Terzolo HR (2005). Chicken egg yolk antibodies (IgY-technology): a review of progress in production and use in research and human and veterinary medicine. Alternatives to Laboratory Animals, 33(2): 129-154. DOI: https://www.doi:10.1177/026119290503300208 
Schade R, Poster C, Halatsch R, and Henklein P (1991). Polyclonal IgY antibodies from chicken egg yolk-an alternative to the production of mammalian IgG type antibodies in rabbits. Alternatives to Laboratory Animals, 19: 403. DOI: https://www.doi.org/10.1177\%2F026119299101900404

Sim JS, Sunwoo HH, and Lee EN (2000). Ovoglobulin IgY. -In Natural Food Antimicrobial Systems. A. S.Naidu, ed. CRC Press, Boca Raton, FL, pp. 227-252.

Smith AL, and Beal R (2008). The avian enteric immune system in health and disease. In: Davison, F., Kaspers, B., Schat, K.A., editors. Avian Immunology. Elsevier Ltd., New York, PP. 243-271.

Sugita-Konishi Y, Sakanaka S, Sasaki K, Juneja LR, Noda T, and Amano F (2002). Inhibition of bacterial adhesion and salmonella infection in BALB/c mice by sialyloligosaccharides and their derivatives from chicken egg yolk. Journal of Agriculture and Food Chemistry, 50(12): 36073613. DOI: https:/www./doi.org/10.1021/jf0116451

Sunwoo HH, Lee EN, Menninen K, Suresh MR, and Sim JS (2002). Growth inhibitory effect of chicken egg yolk antibody (IgY) on Escherichia coli O157:H7. Journal of Food Science, 75: 342-345. DOI: https://doi.org/10.1111/j.1365-2621.2002.tb10310.x

Sunwoo HH, Nakano T, Dixon T, and Sim JS (1996). Immune responses in chicken against lipopolysaccharides of Escherichia coli and Salmonella typhimurium. Poultry Science, 75: 342-345. DOI: https://www.doi.org/10.3382/ps.0750342

Tamilzarasan KB, Manicavasaka Dinakaran A, Selvaraju G, and Dorairajan N (2009). Efficacy of egg yolk immunoglobulins (IgY) against enteric pathogens in poultry. Tamilnadu Journal of Veterinary and Animal Sciences, 5: 264-268. Available at: http://www.tanuvas.ac.in/tnjvas/tnjvas/vol5(6)/264-268.pdf

Tizard I (2002). The avian antibody response. Seminars in Avian and Exotic Pet Medicine, 11(1): 2-14. DOI: https://www.doi.org/10.1053/saep.2002.28216

Tressler RL, and Roth TF (1987). IgG receptors on the embryonic chick yolk sac. Journal of Biological Chemistry, 262: 15406-15412. PMID: 2960667.

Tsubokura K, Berndtson E, Bogstedt A, Kaijser B, Kim M, Ozeki M, and Hammarström L (1997). Oral administration of antibodies as prophylaxis and therapy in Campylobacter jejuni-infected chickens. Clinical and Experimental Immunology, 108: 451-455. DOI: https://www.doi.org/10.1046/j.1365-2249.1997.3901288.x

Ulmer-Franco AM (2012). Transfer of chicken immunoglobulin Y (IgY) from the hen to the chick. Avian Biology Research, 5(2): 81-87. DOI: https://www.doi.org/10.3184\%2F175815512X13350053184471

Vandeputte J, Martel A, Canessa S, Van Rysselberghe N, De Zutter L, Heyndrickx M, Haesebrouck F, Pasmans F, and Garmyn A (2019). Reducing Campylobacter jejuni colonization in broiler chickens by in-feed supplementation with hyperimmune egg yolk antibodies. Science Report, 9: Article number: 8931. DOI: https://www.doi.org/10.1038/s41598-019-45380-z

Vega C, Bok M, Chacana P, Saif L, Fernandez F, and Parreno V (2011). Egg yolk IgY: protection against rotavirus induced diarrhea and modulatory effect on the systemic and mucosal antibody responses in newborn calves. Veterinary Immunology and Immunopathology, 142(3): 156-169. DOI: https://www.doi.org/10.1016/j.vetimm.2011.05.003

Wang XZ, Fan B, Liu LG, Hu XY, Li RY, Wei Y, Wan Z, and Deng XL (2008). In vitro inhibition of oral Candida albicans by chicken egg yolk antibody (IgY). Mycopathologia, 165: 381-387. DOI: https://www.doi.org/10.1007/s11046-008-9097-0

Warr GW, Magor KE, and Higgins DA (1995). IgY: clues to the origins of modern antibodies. Immunology Today, 16(8): 392-398. DOI: https:/www./doi.org/10.1016/0167-5699(95)80008-5

Wiedemann V, Linckh E, Kühlmann R, Schmidt P, and Lösch U (1991). Chicken egg antibodies for prophylaxis and therapy of infectious intestinal diseases. Journal of Veterinary Medicine, 38: 283-291. DOI: https://www.doi.org/10.1111/j.1439-0450.1991.tb00872.X

Wierup M (2000). The control of microbial diseases in animals: alternatives to the use of antibodies. International Journal of Antimicrobial Agents, 14: 315-319. DOI: https://www.doi.org/10.1016/s0924-8579(00)00143-6

Wilkie DC (2006). Non-antibiotic approaches to control pathogens in the gastrointestinal tract of the broiler chicken. PhD Thesis: University of Saskatchewan (Canada).

Williams J (1962). Serum proteins and the livetins of hen's egg yolk. Biochemical Journals, 83: 346-355. DOI https://www.dx.doi.org/10.1042\%2Fbj0830346

Xu Y, Li X, Jin L, Zhen Y, Lu Y, Li S, You J, and Wang L (2011). Application of chicken egg yolk immunoglobulins in the control of terrestrial and aquatic animal diseases: a review. Biotechnology Advances, 29: 860-868. DOI: https://www.doi.org/10.1016/j.biotechadv.2011.07.003

Yegani M, and Korver D (2007). Are egg yolk antibodies an alternative to antibiotics. World Poultry, 23: 5. Available at: https://www.poultryworld.net/Broilers/Health/2007/5/Are-egg-yolk-antibodies-an-alternative-to-antibiotics-WP006829W/

Yegani M, and Korver DR (2010). Application of egg yolk antibodies as replacement for antibiotics in poultry. World's Poultry Science Journal, 66(1): 27-38. DOI: https://www.dx.doi:10.1017/S0043933910000048

Yokoyama H, Peralta RC, Diaz R, Sendo S, Ikemori Y, and Kodama Y (1992). Passive protective effect of chicken egg yolk immunoglobulins against experimental enterotoxigenic Escherichia coli infection in neonatal piglets. Infection and Immunology, 60(3): 998-1007. DOI https://www.ncbi.nlm.nih.gov/pubmed/1347289

Yokoyama H, Peralta RC, Sendo S, Ikemori Y, and Kodama Y (1993). Detection of passage and absorption of chicken egg yolk immunoglobulins in the gastrointestinal tract of pigs by use of enzyme-linked immunosorbent assay and fluorescent antibody testing. American Journal of Veterinary Research, 54(6): 867-872. PMID: 8323054

Yokoyama H, Peralta RC, Umeda K, Hashi T, Icatlo FCJr, Kuroki M, Ikemori Y, and Kodama Y (1998). Prevention of fatal Salmonellosis in neonatal calves, using orally administered chicken egg yolk Salmonella-specific antibodies. American Journal of Veterinary Research, 59(4): 416-420. PMID: 9563623

Yousif AA, Mohammad WA, Khodeir MH, Abo Zeid AA, El-Sanousi AA, Saber MS, and Reda IM (2006). Oral Administration of hyperimmune Ig Y: An immunoecological approach to curbing acute infectious bursal disease virus infection. The Egyptian Journal of Immunology, pp. 1-10. Available at https://pubmed.ncbi.nlm.nih.gov/18689274/

Zhang JJ, Kang TY, Kwon T, Koh H, Chandimali N, Huynh DL, Wang XZ, Kim N, and Jeong DK (2019). Specific chicken egg yolk antibody improves the protective response against Gallibacterium anatis infection. Infection and Immunity, 87: 619-618. DOI: https://www.doi.org/10.1128/iai.00619-18

Zuniga A, Yokoyama H, Albicker-Rippinger P, Eggenberger E, and Bertschinger HU (1997). Reduced intestinal colonisation with F18-positive enterotoxigenic Escherichia coli in weaned pigs fed chicken egg antibody against the fimbriae. FEMS Immunology and Medical Microbiology, 183: 153-161. DOI: https://www.doi.org/10.1111/j.1574-695X.1997.tb01041.X 